The Attitudes of In-Service and Pre-Service Teachers Toward Inclusive Education

\author{
Nur Aisyah Rumalutur ${ }^{\mathrm{a}}$ and Farida Kurniawati ${ }^{\mathrm{b}}$
}

${ }^{a}$ Departement of Educational Psychology, Faculty of Psychology, Universitas Indonesia, Depok, Indonesia; ${ }^{b}$ Departement of Educational Psychology, Faculty of Psychology, Universitas Indonesia, Depok, Indonesia

*Corresponding Authors:

Farida Kurniawati

Department of Educational Psychology

Faculty of Psychology, Universitas Indonesia

J1. Lkr. Kampus Raya, Depok, Jawa Barat

Indonesia, 16424

Tel.: +62 217270004

Email address: farida1@ui.ac.id / fafadana@gmail.com 


\title{
The Attitudes of In-Service and Pre-Service Teachers Toward Inclusive Education
}

\begin{abstract}
Attitude is a disposition to respond favorably or unfavorably to an object, person, institution, or event. Someone's attitude could be inferred from her or his knowledge, affect, or conation toward objects, persons, institutions, or events. The aim of this study is to examine pre-service and in-service teachers' attitudes toward inclusive education (IE) in regular preschool in Indonesia. There are 185 participants (100 pre-service teachers and 85 in-service teachers) in this study. Respondents were collected by accidental and purposive sampling. Participants were asked to complete a scale about attitudes toward IE and students with special education needs through self-report. Independent sample $t$-test, onesample $t$-test, and descriptive methods were used to analyze data. The results showed that there are significant differences between the attitudes of pre-service and in-service teachers toward inclusive education. In-service teachers showed more positive attitudes toward IE and students with special education needs rather than pre-service teachers in cognitive aspects. Pre-service and in-service teachers who had experience in IE training showed more positive attitudes than teachers who had not.
\end{abstract}

Keywords: inclusive education, attitude, teaching experience, interaction with students with special educational needs, training experience.

\section{Introduction}

Inclusive education (IE) is an education system that provides opportunities for all students who have special needs and intelligence potential to attend school in an general education classroom environment (Permendiknas No. 70/2009 Article 1). This regulation is an effort by the government to provide equitable, broad, and non-discriminatory education to every community, including students with special educational needs (SENs). SENs, according to Kirk et al. (2015) (as cited in Maulia \& Kurniawati, 2018), are students who are different from regular students in mental characteristics, sensory abilities, communication skills, emotional and behavioral development, and/or physical characteristics. The Regulation of the Minister of National Education No. 70 stated that the implementation of IE began from the level of kindergarten/early childhood education until university. The application of IE at the kindergarten level was the most recent addition to the program, with the intention of providing early education opportunities to SENs as well as regular students.

Data from the Ministry of Education and Culture (Kemdikbud) states that of 1.6 million SENs in 2017 , only $18 \%$ received education services ( special schools $=115,000 ; \mathrm{IE}=299,000$ ) (Maulipaksi, 2017). The data shows that there were still many SENs who did not receive an education as promised in the constitution. One factor that may influence access to special education in big cities is its large expense; the government continues to improve regular schools to implement IE so that SENs could easily access the education. In addition, IE provides 
opportunities for SENs's social and emotional development through interaction with regular students in their daily lives.

As IE increases, the school has to adapt policies, infrastructure, curriculum, staff, and teachers so that regular students and SENs can learn appropriately. In fact, since the adoption of IE in 2004, there have been obstacles in implementing and identifying its goals. There were unpleasant behaviors, both from regular students and teachers, in reaction to inadequate infrastructure. For example, there were many instances of the type of bullying toward SENs that often occurs from elementary schools to universities (www.koran-sindo.com; jakarta.tribunnews.com; www.kompas.com). It is often found that teachers are not ready to handle SENs and have difficulty applying the right learning methods. In the end, teachers chose to be silent or ignore the SENs when they found that SENs were having a hard time with learning materials. In addition, a curriculum that was not able to meet the diverse needs of regular students and SENs in the classroom added to the difficulties of implementing IE in inclusive schools (Rombot, 2017; blogruangguru.com, 2016). The presence of IE since preschool can provide an earlier and more positive education experience for SENs, better preparing SENs for future educational experiences.

The success of IE is influenced by several factors, including competent human resources, availability of support services in schools, equipment, adequate space to meet the needs of SENs, and the teacher's positive attitude toward inclusive education (Wesley, Buysse, \& Tyndale, 1997; Wolery et al., 1994; Hammond \& Ingalls, 2003; Wolery et al., 1993; Niemeyer $\&$ Proctor, 2002). Various studies agree that teachers are the key factor in the success of IE because they spend the most time with regular students and SENs in the classroom (Leatherman \& Niemeyer, 2005; Leung \& Mak, 2010; Avramidis \& Norwich, 2015; Florian, 2017; Shade \& Stewart, 2000). The teacher's position as a catalyst to make changes in the direction of education means his or her positive attitude toward IE becomes a prerequisite for success. The teacher is responsible for meeting the needs of students in an increasingly diverse classroom with the application of IE (Goddard \& Evans, 2018).

\section{Literature}

Fakolade, Olufemi, and Tella (2009) state that the most important aspect of teachers is their attitude. Teachers' attitudes toward self, work, students, and others affect productivity and acceptance or even rejection of the implementation of IE. Attitude itself is a disposition of someone to respond favorably (positive, like, agree, happy, etc.) or unfavorably (negative, dislike, disagree, dislike, etc.) toward objects, people, institutions, and circumstances (Ajzen, 2005 , p. 3). A person's perceived attitude often predicts his or her response to a situation, including the response to SENs (Delgado, 2011). A person's attitude toward stimulus was reflected in cognitive, affective, or conative responses (Ajzen, 2005). In the context of IE, the cognitive component describes one's knowledge of IE and SENs, the affective component is related to how a person feels about SENs, and conative components relate to a person's tendency to act when facing SENS (Triandis, 1971, as cited in Leatherman \& Niemeyer, 2005). In fact, teachers' attitudes toward IE tend to be complex and different between teachers and schools (Fakolade et al., 2009). Some studies have found teacher attitudes vary with IE (Bradshaw \& 
Mundia, 2006). According to Norwich (1994), teacher acceptance, support, or rejection of IE influenced commitment to implementing IE. Teachers who are positive about students can increase good interaction between themselves and students (Leyser \& Tappendorf, 2001; Atta, Shah, \& Khan, 2009; Ahsan et al., 2012). Likewise, students who perceive teachers as having positive attitudes tend to show high satisfaction or success in learning and have low anxiety (Monsen \& Frederickson, 2004). Teachers with positive attitudes toward IE will make every effort to provide opportunities for students and further increase the success rate of students in the classroom (Elliot, 2008, as cited in Fakolade et al., 2009).

Still, if a few teachers reject the application of IE, that can impact involvement of SENs in regular classes, especially those with more severe learning differences or who need assistance in mobility (Bradshaw \& Mundia, 2006; Avramidis \& Norwich, 2002; Schmidt \& Vrhovnik, 2015; Arthur et al., 1999; NSW Government, 2012; New Zealand Government, 2016). On the other hand, Sharma, Ee, and Desai (2006) explained that the implementation of IE in the class also depends on the preparation process of pre-service teachers while in universities. This argument is strengthened by Forlin (2006), who stated that pre-service teachers need consistency of development related to IE to ensure that the needs of SENs are met appropriately. This is also stated in Government regulation No. 70/2009 Article 10, which requires provincial/city/district governments to improve teacher competency in IEs - one way of doing this is through universities. Research has shown that pre-service teachers who were prepared earlier had increased self-efficacy and self-confidence in teaching SENs and have a positive attitude toward IE (Bechham \& Rouse, 2011; Shade \& Stewart, 2001). Therefore, the attitude of pre-service teachers is also an important component in the implementation of IE (Forlin et al., 2009; Brownlee \& Carrington, 2000). Sze (2009) states that forming a positive attitude toward SENs becomes an important aspect in educating pre-service teachers. It is a university's responsibility to ensure that pre-service teachers have a professional attitude toward IE and are confident in their abilities to meet the needs of SENs and regular students (Brackenreed \& Barnett, 2006; Forlin et al., 2003).

The positive attitude of in-service teachers toward IE will be formed if there is training, knowledge about SENs' characteristics, accompaniment of special teachers in the classroom, and support from schools (Dinnebeil, McInerney, Fox, \& Juchartz-Pendry, 1998; Rose \& Smith, 1993; Odom \& McEvoy, 1990). For pre-service teachers, a positive attitude is formed when attending courses related to strategies in handling SENs and internships involving direct interaction with SENs (Miller \& Stayton, 1996; Proctor \& Niemeyer, 2001). De Boer (2014), through the study about variables related to teachers' attitudes, became convinced that experience, training, and interaction with SENs were the variables that most influence the attitude of teachers about SENs. Research has found that in-service teachers who were more experienced with SENs had a more positive attitude than those who lack experience (Delgado, 2011). This even applies to mere interactions with SENS; in-service teachers who had interacted and had close contact with individuals with special needs had more positive attitudes toward IE than those who did not (Bender, Vail \& Scott, 1995; Cox, 1994; Harvey \& Green, 1984, as cited in Sharma et al., 2003). The experience of interaction with individuals with special needs, such as friends, relatives, and children or through films or books, can form a positive attitude toward 
SENs. Furthermore, with regard to training, in-service teachers will have more commitment to including SENs in regular classes after completing IE practice directly and understanding the practices and skills needed in implementing IE (Villa, Thousand, Meyers, \& Nevin, 1996, as cited in Delgado, 2011). In addition, in-service teachers who earned professional qualifications have more positive attitudes toward SENs in IE settings than in-service teachers who do not have professional qualifications (Fakolade et al., 2009).

In addition, research on the attitudes of pre-service teachers to IE shows that pre-service teachers felt pre-service programs only provided general information about IE; they felt a need to participate in additional workshops, seminars, courses, and internships in inclusive classes to improve their knowledge (Crane-Mitchell Hedge, 2007, as cited in Akalin, Demir, Sucuoglu, Bakkaloglu, \& Iscen, 2014). Thaver, Lim, and Liau (2014) indicated that pre-service teachers who had attended training related to SENs showed more positive attitudes toward SENs at inclusive schools than pre-service teachers who had not attended training. Pre-service teachers who had little or no experience in interaction with SENs tended to showed anxiety and lack confidence in their ability to effectively teach SENs (Everhart, 2009; D'Alonzo, Giordano, \& VanLeeuwen, 1997). Demir, Sucuoglu, Bakkaloglu, and Iscen (2014) stated that preschools teachers generally support the idea of IE but usually did not want SENs in their classes because they lacked knowledge and skills related to IE practices. Therefore, in-service teachers and preservice teachers need to have adequate knowledge about SENs and direct interaction experience so that they know the effort necessary meet their students' needs (Crane-Mitchell \& Hedge, 2007 in Alkalin, 2014).

\section{Method}

\section{Respondents, Procedure, and Instrument}

A total of 100 in-service teachers and 85 pre-service teachers participated in this study. Preservice teachers are undergraduate students in the final level (Semester 5-9) of their study; some already graduated. All of the pre-service teachers were from Universitas Negeri Jakarta majoring in early childhood education and special needs education, whereas in-service teachers were from private preschools in Jabodetabek, Makasar, Bandung, and Medan. This city was chosen in terms of the feasibility of access to study respondents. This study took place over one month (September 2018). Pre-service teachers were obtained through field study at Universitas Negeri Jakarta, while in-service teachers were identified though social media messenger applications like WhatsApp and field study in some schools. Pre-service teachers were assessed through purposive sampling technique, while in-service teachers were assessed through accidental sampling techniques.

The respondents were asked to complete a questionnaire that contained an attitude scale toward inclusive education through Google form and questionnaire booklets. The scale measuring the attitude toward IE consisted of three aspects, cognitive, affective, and conative, measured using a Multidimensional Attitudes questionnaire toward Inclusive Education Scale Indonesian Version (MATIES-IV) by Sihombing (2014) adapted from the same scale by Mahat (2008). The MATIES-IV questionnaire has a good validity coefficient, between 0.26-0.80, and high 
reliability of the three components with alpha values (cognitive $[\alpha=0.77]$, affective $[\alpha=0.80]$, conative $[\alpha=0.81])$. This MATIES-IV consisted of 18 items representing the cognitive (6 items), affective (6 items), and conative aspects ( 6 items). Three items of cognitive aspects are unfavorable, all affective items are unfavorable, and conative items are all positive. The scale used a six-point Likert type scale, ranging from 1 to $6(1=$ strong disagreement and $6=$ strong agreement).

The data was self-reported by all respondents about their attitudes toward IE; respondents were also asked to report their training experience so researchers could assess whether training experiences gave different contribution to respondents' attitudes. An attitude was measured by MATIES-IV scale; the training experience was measured through demographics data. This study does not conduct training around IE to see the effect on in-service and pre-service teachers' attitude but rather uses descriptive methods to know if training experience influenced respondents' attitudes.

\section{Hypothesis and Data Analysis}

The variables of this study were attitudes consisting of cognitive, affective, and conative aspects. The attitude of in-service and pre-service participants was measured in detail for each aspect. The cutting point used to measure respondents' attitude was Mean point. The respondents who had a total score above Mean are considered to have a positive attitude while under Mean is considered to have a negative attitude toward IE.

The hypotheses of this study are as follows:

- There are significant differences in attitudes between in-service and pre-service teachers toward IE.

- There are significant differences in each aspect of attitude of in-service teachers toward IE.

- There are significant differences in each aspect of attitude of pre-service teachers toward IE.

- There are significant differences in attitude of in-service teachers toward IE in terms of training experience.

- There are significant differences in attitude of pre-service teachers toward IE in terms of training experience that they were taken.

The data obtained will be analyzed using statistical techniques with independent sample $t$-tests to compare the two groups, one-sample $t$-test, and descriptive interpretations. The statistical techniques will be presented in SD, Mean and frequency to analyze the data collected, and the significance point used in this study were $p=.05$ and $p=.001$. 


\section{Results}

Table I. Demographics Data of In-Service and Pre-Service Teachers

\begin{tabular}{|c|c|c|}
\hline Demographics & $\begin{array}{c}\text { In-service } \\
(N=85)\end{array}$ & $\begin{array}{c}\text { Pre-service } \\
(N=\mathbf{1 0 0})\end{array}$ \\
\hline & $N$ & $N$ \\
\hline \multicolumn{3}{|l|}{ Gender } \\
\hline Male & 4 & 10 \\
\hline Female & 81 & 90 \\
\hline \multicolumn{3}{|l|}{ Programs } \\
\hline Early childhood education & - & 38 \\
\hline Special education & - & 62 \\
\hline \multicolumn{3}{|l|}{ Semesters } \\
\hline $5-7$ & - & 43 \\
\hline 8 & - & 43 \\
\hline $9-13$ & - & 10 \\
\hline Graduated & - & 4 \\
\hline \multicolumn{3}{|l|}{ Educational level } \\
\hline High school & 11 & - \\
\hline Diploma & 6 & - \\
\hline Undergraduate & 60 & 100 \\
\hline Postgraduate & 8 & - \\
\hline \multicolumn{3}{|l|}{ Training experience } \\
\hline Yes & 85 & 70 \\
\hline No & - & 30 \\
\hline \multicolumn{3}{|l|}{ Teaching experience } \\
\hline $1-4$ years & 29 & - \\
\hline 5-9 years & 23 & - \\
\hline $10-14$ years & 13 & - \\
\hline$>14$ years & 20 & - \\
\hline \multicolumn{3}{|c|}{ Internship with SENs/IE } \\
\hline Never & - & 16 \\
\hline$<3$ months & - & 53 \\
\hline 4-12 months & - & 17 \\
\hline $1-3$ years & - & 13 \\
\hline$>3$ years & - & 1 \\
\hline
\end{tabular}

Descriptive methods of data demographics show that, in this study, there are more female respondents than male in both in-service and pre-service teachers. Most respondents have higher educational level and most had experience with SENs through teaching experience or interaction with SENs. Most in-service teachers in this study have between one and nine years of teaching experience with IE and SENs. Meanwhile, most pre-service teachers had little experience interacting in regular time with SENs. 
Table II. The Attitudes of In-Service and Pre-Service Teachers toward IE

\begin{tabular}{|c|c|c|c|c|c|c|}
\hline Participants & Attitudes & $N$ & $M$ & $S D$ & $t$ & $p$ \\
\hline In-Service & Cognitive & 85 & 4.67 & 0.77 & 4.449 & $.000 * *$ \\
\hline Pre-Service & & 100 & 4.17 & 0.74 & 4.435 & $.000 * *$ \\
\hline In-Service & Affective & 85 & 4.56 & 0.81 & 1.701 & .091 \\
\hline Pre-Service & & 100 & 4.34 & 0.95 & 1.723 & .087. \\
\hline In-Service & Conative & 85 & 5.08 & 0.73 & 0.905 & .367 \\
\hline Pre-Service & & 100 & 4.99 & 0.66 & 0.897 & .371 \\
\hline
\end{tabular}

An independent sample t-test indicated that there were significant differences of attitude toward IE and SENs only in cognitive aspects. In-service teachers showed more positive attitudes toward IE and SENs $(M=4.67, S D=0.77)$ than pre-service teachers $(M=4.17, S D=0,74), t$ $=4.449, \mathrm{p}<.001$. There were no different attitudes toward IE in affective and conative aspects for either in-service or pre-service teachers.

Table III. An Attitude of In-Service Teachers toward IE

\begin{tabular}{ccccccc}
\hline \multicolumn{2}{c}{ Variable } & $\mathbf{N}$ & $\mathbf{M}$ & $\mathbf{S}$ & $\mathbf{t}$ & $\mathbf{p}$ \\
\hline Attitude & Cognitive & & 4.67 & 0.77 & 56.110 & $.000^{* *}$ \\
& Affective & 85 & 4.56 & 0.80 & 52.074 & $.000^{* *}$ \\
& Conative & & 5.08 & 0.73 & 63.862 & $.000^{* *}$ \\
\hline
\end{tabular}

One-sample $t$-test indicated that in-service teachers have positive attitudes toward IE in three aspects: cognitive $(M=4.67, S D=.77, t=56.110)$, affective $(M=4.56, S D=.80, t=52.074)$, and conative $(M=5.08, S D=.73, t=63.862), p<.001$.

Table IV. An Attitude of Pre-Service Teachers toward IE

\begin{tabular}{ccccccc}
\hline \multicolumn{2}{c}{ Variable } & $\mathbf{N}$ & $\mathbf{M}$ & $\mathbf{S D}$ & $\mathbf{t}$ & $\mathbf{p}$ \\
\hline Attitude & Cognitive & & 4.17 & 0.73 & 56.510 & $.000^{* *}$ \\
& Affective & \multirow{2}{*}{100} & 4.34 & 0.95 & 45.749 & $.000^{* *}$ \\
& Conative & & 4.99 & 0.66 & 75.869 & $.000^{* *}$ \\
\hline
\end{tabular}

One-sample $t$-test indicated that pre-service teachers also have positive attitudes toward IE in three aspects: cognitive $(M=4.17, S D=.73, t=56.510)$, affective $(M=4.34, S D=.95, t=$ 47.749), and conative $(M=4.99, S D=.66, t=75.869), p<.001$. 
Table V. An Attitude of In-Service Teachers toward IE in Terms of Training Experience

\begin{tabular}{llccccc}
\hline $\begin{array}{c}\text { Training } \\
\text { Experience }\end{array}$ & Atittudes & N & M & SD & t & p \\
\hline Yes & Cognitive & 57 & 4.78 & 0.79 & 2.044 & $.044 * *$ \\
No & & 28 & 4.43 & 0.67 & & \\
& & & & & \\
Yes & Affective & 57 & 4.73 & 0.79 & 2.892 & $.005 * *$ \\
No & 28 & 4.21 & 0.74 & & \\
& & & & & \\
Yes & Conative & 57 & 5.18 & 0.75 & 1.815 & .073 \\
No & & 28 & 4.88 & 0.67 & & \\
\hline \multicolumn{5}{c}{$* *<<.05$}
\end{tabular}

An independent sample t-test indicated that training experience in IE or SENs had significant impacts on pre-service teachers' attitudes toward IE in cognitive $(\mathrm{M}=4.78, \mathrm{SD}=.79, \mathrm{t}=2.044)$ and affective aspects $(\mathrm{M}=4.73, \mathrm{SD}=.79, \mathrm{t}=2.892), \mathrm{p}<.05$, but not in conative aspects.

Table VI. An Attitude of Pre-Service Teachers toward IE in Terms of Training Experience

\begin{tabular}{llccccc}
\hline $\begin{array}{c}\text { Training } \\
\text { Experience }\end{array}$ & Atittudes & N & M & SD & $\mathbf{t}$ & $\mathbf{p}$ \\
\hline Yes & Cognitive & 70 & 4.24 & 0.81 & 1.295 & .198 \\
No & & 30 & 4.03 & 0.51 & & \\
& & & & & & \\
Yes & Affective & 70 & 4.46 & 0.97 & 2.021 & $.046^{* *}$ \\
No & & 30 & 4.05 & 0.83 & & \\
& & & & & & \\
Yes & Conative & 70 & 5.11 & 0.61 & 2.832 & $.006^{* *}$ \\
No & & 30 & 4.71 & 0.70 & & \\
\hline & & $* * p<.05$ & & &
\end{tabular}

Conversely, an independent sample $t$-test indicated that training experience about IE or SENs significantly impacted pre-service teachers' attitudes toward IE in affective $(M=4.46, S D=.97$, $t=2.021)$ and conative aspects $(M=5.11, S D=.61, t=2.832), p<.05$ but not in cognitive aspects.

\section{Discussion}

The study revealed that both in-service and pre-service teachers in Indonesia showed positive attitudes toward IE in all three aspects. It explains that both in-service and pre-service teachers have knowledge about IE and SENs. This could have happened because most of the in-service participants have teaching experience and have interacted with SENs for more than 7 yearssome more than 14 years. For the pre-service teachers, knowledge about IE and SENs was acquired from their college majors; most of the pre-service participants majored in early childhood education, psychology, and education of special needs. As a result of the positive knowledge and attitudes toward IE, both participants will have showed positive tendency to act 
when facing IE or SENs (Triandis, 1971, as cited in Leatherman \& Niemeyer, 2005; Fakolade et al., 2009; Bradshaw \& Mundia, 2006).

The comparative study with independent $t$-test showed that in-service teachers have more knowledge about IE and SENs than pre-service teachers. This is probably because in-service teachers have more experience with the implementation of IE and interacting with SENs, so they know much more about how to handle SENs and the reality of implementation of IE. Data collecting showed that most in-service teachers in this study had more than 14 years of teaching experience and interaction with SENs. Meanwhile, pre-service teachers had less than 3 years' teaching experience. It also showed that pre-service teachers have experience with SENs only through internship that last between one week and one moth. This is in line with studies that found that pre-service teachers consider educational programs as only providing general information about IE, so they feel they need to get additional workshops, seminars, courses, and internships in inclusive classes to improve their knowledge (Crane-Mitchell Hedge, 2007, as cited in Akalin et al., 2014). Affective and conative aspects showed no significant difference between in-service and pre-service teachers. This is likely because affective aspects involved feeling, and most people will show sympathy and empathy toward SENs. It is no different with conative aspects - most people will tend to act positively toward SENs in the IE situations. These conative aspects just showed the tendency of someone's behavior but not the actual behavior in real situations.

The results of training experiences showed that there is a significant difference between participants, in-service teachers and pre-service teachers who had sit-in training and who did not. This is in line with studies that revealed that in-service teachers who had interacted and had close contact with individuals with special needs had more positive attitudes toward IE than those who did not (Bender, Vail \& Scott, 1995; Cox, 1994; Harvey \& Green, 1984, as cited in Sharma et al., 2003). But the results showed the different effects of training aspects of attitudes. Training experience of in-service teachers had significant effects on both cognitive and affective aspects but not conative aspects. In-service teachers probably will tend to not interact positively with SENs or the implementation of IE because of lack of support from schools, poor infrastructure, or lack of a special needs assistant. These factors may inhibit their behavior in actual situations. These results differ in that pre-service teachers who had training experience showed more positive attitude of affective and conative aspects than who those had not. However, there is no difference in knowledge aspects. It showed that most pre-service teachers have good knowledge about the implementation of IE and SENs, but pre-service teachers who had training experience showed more positive feeling and will tend to act more positively in real-life situations with SENS.

\section{Limitations}

There were several limitations regarding the methods in this study. This study did not compare demographic data in terms of income or age. Therefore, future research can consider using ANOVA statistical techniques to compare demographic factors in these two groups. This research also only uses students from one university in Jakarta and is limited to early childhood education and special education programs. It would be good if the future research could see the 
attitudes of students from various universities and other study programs. Further research also can find out how the attitude of social workers who had volunteered in IE.

\section{Conclusion}

The researcher found that the attitudes of in-service and pre-service teachers toward inclusive education were positive in all three aspects of attitudes. There is no significant difference for affective and conative aspects in both respondents' attitudes. In-service and pre-service teachers who had training experience showed more positive attitudes on cognitive and affective aspects than teachers who had no training experience. This study provides more knowledge about the importance of teachers' knowledge about IE and SENs in influence teacher behavior toward students. It also showed that training always had a positive impact on teachers' attitude. Therefore, governments should include updated IE training as one of the regulations for inservice programs to optimize teachers' abilities to provide SENs with meaningful education in general education classrooms.

\section{References}

Ajzen, I. (2005). Attitudes, personality and behaviour (2nd ed.). Maidenhead, UK: Open University Press. doi:10.1037/e418632008-001

Akalin, S., Demir, S., Sucuoglu, B., Bakkaloglu, H., \& Iscen, F. (2014). The needs of inclusive preschool teachers about inclusive practices. Eurasian Journal of Educational Research, 54, 39-60.

Atta, M. A., Shah, M., \& Khan, M. M. (2009). Inclusive school and inclusive teacher. The Dialogue, 4(2), 272283.

Avramidis, E., \& Norwich, B. (2002). Teachers' attitudes towards integration/inclusion: A review of the literature. European Journal of Special Needs Education, 17(2), 129-147. doi: 10.1080/08856250210129056

De Boer, A. (2014). Inclusion: a question of attitudes? A study on those directly involved in the primary education of students with special educational needs and their social participation. Retrieved from: https://www.researchgate.net/publication/254821772

Delgado, J. (2011). Early childhood teacher attitudes regarding inclusion (Doctoral dissertation). Oklahoma State University Stillwater, Oklahoma.

Fakolade, A., Olufemi, S., \& Tella, A. A. (2009). Attitude of teachers towards the inclusion of special needs children in general education classroom: the case of teachers in some selected schools in Nigeria. International Electronic Journal of Elementary Education, 1(3), 155-169.

Leatherman, J., \& Niemeyer, J. (2005). Teachers' attitudes toward inclusion: Factors influencing classroom practice. Journal of Early Childhood Teacher Education, 26(1), 23-36. doi:10.1080/10901020590918979

Leung, C., \& Mak, K. (2010). Training, understanding, and the attitudes of primary school teachers regarding inclusive education in Hong Kong. International Journal of Inclusive Education, 14(8), 829-842. doi:10.1080/13603110902748947

Leyser, Y., \& Tappendorf, K. (2001). Are attitudes and practices regarding mainstreaming changing? A case of teachers in two rural school districts. Education, 121(4), 751-760.

Mahat, M. (2008). The development of a psychometrically-sound instrument to measure teachers' multi dimensional attitudes toward inclusive education. International Journal of Special Education, 23(1), 8292.

Maulia, M., \& Kurniawati, F. (2018). Inclusive education in primary school: Do teachers' attitudes relate to their classroom management?. In Ariyanto et al. (Eds.), Diversity in Unity: Perspectives from Psychology and Behavioral Sciences. Taylor \& Francis Group, London. ISBN 978-1-138-62665-2 
Maulipaksi, D. (2017). Sekolah inklusi dan pembangunan SLB dukung pendidikan inklusi. Kementrian Pendidikan dan Kebudayaan. Retrieved from: https:/www.kemdikbud.go.id/main/blog/2017/02/sekolahinklusi-dan-pembangunan-slb-dukung-pendidikan-inklusi

Monsen, J. J., \& Frederickson, N. (2004). Teachers' attitudes towards mainstreaming and their puIEls' perceptions of their classroom learning environment. Learning Environments Research, 7(2), 129-142. doi:10.1023/B:LERI.0000037196.62475.32

Norwich, B. (1994). The relationship between attitudes to the integration of children with special educational needs and wider socio-political views: A US-English comparison. European Journal of Special Needs Education, 9(1), 91-106. doi:10.1080/0885625940090108

Peraturan Menteri Pendidikan Nasional (Permendiknas) RI No. 70 tahun 2009.

Sharma, E. U., Ee, J., \& Desai, I. (2003). A comparison of australian and singaporean pre-service teachers' attitudes and concerns about inclusive. Teaching and Learning, 24(2), 207-217.

Sihombing, C. M. (2014). Hubungan antara sikap terhadap pendidikan inklusif dan strategi pengajaran pada guru SD Negeri Inklusif dan SD Swasta Inklusif (Master thesis). Universitas Indonesia, Depok, Indonesia.

Thaver, T., Lim, L., \& Liau, A. (2014). Teacher variables as predictors of Singaporean pre-service teachers' attitudes toward inclusive education. Published by International Association of Social Science Research, 1(1) $1-8$.

UUD 1945. Retrieved from: http://www.bpn.go.id/PUBLIKASI/Peraturan-Perundangan/UndangUndang/undang-undang-dasar-1945-931 